\title{
Patients and Caregivers' Understanding of Pressure Injury Risk Factors and Their Participation in Care
}

\author{
Rose Ekama Ilesanmi ${ }^{1}$, Bolaji Funke Olayinka ${ }^{2}$ \& Victoria Funmilayo Hanson ${ }^{1}$ \\ ${ }^{1}$ College of Nursing, Rak Medical and Health Sciences University, Ras Al-Khaimah, United Arab Emirate \\ ${ }^{2}$ University College Hospital, Ibadan. Nigeria \\ Correspondence: Rose Ekama Ilesanmi, Assistant Professor, College of Nursing, Rak Medical and Health \\ Sciences University, Ras Al-Khaimah, United Arab Emirate. Email: rose@rakmhsu.ac.ae
}

Received: April 14, 2019

doi:10.20849/ijsn.v4i2.574
Accepted: April 30, 2019

Online Published: May 7, 2019

URL: https://doi.org/10.20849/ijsn.v4i2.574

\begin{abstract}
Background: Recommendations to prevent pressure injuries (PI) consistently emphasize patients' participation in care, without which interventions are less likely to be effective. Aim: To examine patients and/or their caregivers' knowledge of risk factors and participation in PI preventive interventions.

Subjects and Methods: This descriptive study was conducted among 70 patients in neurological and orthopaedic wards in the University College Hospital in Nigeria. The patients were purposively selected. Knowledge about risk factors for PI, level of participation in care and perceived barriers were examined using structured questionnaire.

Findings: Mean age was age 49 \pm 18years; $37(66.1 \%)$ did not consider they were at risk for PI. Poor knowledge of risk factors: incontinence $(59.3 \%)$, dragging self out of bed (56.5\%), loss of sensation (58.3), when the nurse drags than lifts $(66.7 \%)$ was found. Mean knowledge of risk factors was $1.42 \pm 0.49$ and level of participation $(1.31 \pm 0.47)$. Barriers to participation included inadequate instruction from nurses about what they or their caregivers needed to do $(2.41 \pm 1.16)$; pain during repositioning $(3.58 \pm 1.16)$; feeling incompetent to turn

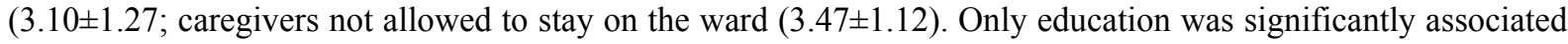
with level of participation $(\mathrm{P}=0.002<0.05)$. However, no significant association existed between the medical diagnosis of the patients and their level of participation $(\mathrm{P}=0.347>0.05)$.

Conclusion: Patients' knowledge of risk factors was poor and participation was also low. Well defined instructions should be provided during hospitalization to improve patient's participation in care.
\end{abstract}

Keywords: patients' participation, pressure injury prevention, patients' roles in PI prevention, risk factors for PI

\section{Introduction}

Pressure injury (PI) previously termed pressure ulcer is a significant patient safety and quality healthcare issue and remains one of the major healthcare problems around the world, with major impact on the health care system, patients and their families (Moore, Cowman \& Conroy, 2011; Cilibertia et al. 2014); yet PI is preventable. Recommendations in Clinical Practice Guidelines (CPG) emphasize patients' participation for better outcomes (Black et al., 2011; Mclnnes et al., 2014; National Pressure Ulcer Advisory Panel, European Pressure Ulcer Advisory Panel and Pan Pacific Pressure Injury Alliance,(NPUAP/EPUAP/PPPIA) 2014). In the light of this, there is increased focus on the prevention and early detection of PI in healthcare organizations, with simple interventions such as moving, repositioning, rehydration and skincare (Black et al., 2011; NPUAP/EPUAP/PPPIA 2014). These interventions are easily understood and carried out by patients. It is reported that these interventions though simple, are less likely to be effective if patients are not fully engaged (Schofield, Porter-Armstrong \& Stinson (2014); NPUAP/EPUAP/PPPIA 2014). Literature confirms the willingness of patients to participate in certain aspects of their care, only when they have sufficient information through targeted instructions/education (Mclnnes et al., 2014; Tobiano, Bucknall, Marshall, Guinane \& Chaboyer, 2016). Yet this area is not adequately explored with regards to PI prevention. In fact, following an extensive review of literature, we found only two studies which were conducted in Australia. These studies explored the perceived roles of patients in preventing pressure injury (Mclnnes et al., 2014; Latimer, Chaboyer \& Gillespie, 2014). According to the authors, patients would prefer to play proactive roles. This suggests that the extent to 
which patients would participate in PI prevention is greatly determined by the information provided to them by nurses, as well as their cognitive and functional status. Similar studies are however lacking currently in Nigeria.

\subsection{Purpose of Study}

The purpose of this study was to examine patients and/or their caregivers' knowledge of risk factors and participation in PI preventive interventions.

\subsection{Literature Review}

Patients' participation is a concept which integrates patients into their care and potentially improve clinical outcome (Näsström et al.; 2014). This trend is contrary to the historical paternalistic model of care whereby the patient played a passive role throughout the care trajectory (Souliotis, 2016). In the current healthcare arena, the trend is geared towards promoting partnership with patients; such that they play active roles in decisions regarding their health.

Patients' participation has been entrenched as a measure of quality of care which cannot be assumed (Mclnnes, Chaboyer, Murray, Allen \& Jones, 2014; Schoeps et al, 2016). According to some authors patients' participation connotes patients' "involvement", "collaboration" "partnership and 'empowerment" (Kuijpers, Groen, Aaronson \& Harten, 2013; Shaghayegh, Leila, Somayeh \& Zeinan, 2014). This suggests active involvement of patients in information-sharing, such that they comply with recommendations (Rafii, Soleimani \& Seyed-Fatemi, 2010). Other authors like Aujoulat, d'Hoore \& Deccache (2007) explained that patients' empowerment reflects the ability of patients to positively influence their health and behaviour, thereby contributing to the overall control of their health and health behaviour. However, effective communication between the care provider and the patients during the care interaction is an essential ingredient. Furthermore, literature explains that when patients and families play active roles in care, such experiences boost their control, facilitate independence and recovery (Shaghayegh et al., 2014). Therefore, effective participation requires targeted efforts to improve patients' access to information and further provide appropriate systems and tools that may help patients in decision making for better clinical outcome. As important as it is for patients and families to participate in providing care during hospitalization, patients' involvement is however not without limitations. For example, Kolovos et al. (2011), opined that involving patients in their safety practices depends on the complexity of the task, as it may also raise a feeling of challenging the healthcare professional's behaviour or adopting an unfamiliar action.

\section{Method and Techniques}

\subsection{Design}

A descriptive design was adopted

\subsection{Setting}

The study was conducted in two selected wards (neurological and orthopaedic wards) in the University College Hospital (UCH), Ibadan Nigeria. This is a 928- bedded hospital with staff capacity of about 1000 nurses and 500 doctors in various specialities and certifications. There are 12 clinical units including neurological and orthopaedics units.

\subsection{Sampling Technique}

The units (neurosurgery $\&$ orthopaedic units) were selected purposively. This is because most patients in these wards experience limited mobility which contributes to PI development.

\subsection{Patient Selection}

A total sample of adult patients on the wards at the time of study were recruited, using a calculated sample size of 78 patients $\left[\mathrm{n}=\mathrm{N} \div 1+\mathrm{N}\left(\mathrm{e}^{2}\right)\right]$

The patients were distributed proportionally between the two units based on the total number of patients on each ward as follows 43: Neurology; 33 orthopaedics.

\subsection{Instrument}

A validated structured questionnaire that was subjected to split-half test of reliability was used. The calculated Cronbach's alpha $=0.75$, indicating good internal consistency. Content validity was checked by an expert in the field. The questionnaire was written in English and translated into the local language using back translation. This was done in order to reach out to patients who could not speak or write English. The questionnaire was divided into sections with 10 items on demographic data; 20 items examined patients and their caregivers' knowledge of risk factors for PI and 16 items assessed their knowledge of interventions to prevent PI. The respondents' level of participation was measured using a 4-point Likert scale ( always $=3$, occasionally $=2$, very rarely $=1$, Never $=0$ ) 
with 14 items. We also examined respondents' perceived barriers to participation in PIP using a 3-point Likert scale $($ Agree $=3$, Undecided $=2$, Disagree $=1$ )

\subsection{Ethical Considerations}

The study was approved by the institutional review board (UI/EC/15/0378). We sought written consent from the participants after detail explanation was provided. Neither the patients nor their caregivers were coerced to participate. Their participation was completely voluntary.

\subsection{Data Analysis}

Data were cleaned, coded and analysis was done using SPSS version 20.0. Data were presented using descriptive statistics. Chi-square test of association for categorical variables was tested; while Analysis of variance (ANOVA) was used to examine the within and between group differences across the wards and participation. The level of significance was set at $0.05 \%$.

\section{Results}

\subsection{Demographic Characteristics}

Of the 78 questionnaires distributed, 70 were suitable for analysis, giving $89.7 \%$ response rate. The respondents' mean age was $49 \pm 18$. They were more males 41 (58.6\%) than female $29(41.4 \%)$. Of these $47.8 \%$ were married, $46.3 \%$ were high school graduates being their highest level of education. In relation to the reason for admission, $35(50 \%)$ was due to spinal cord or head injury while $35.7 \%$ for orthopaedic injuries and surgeries (Table 1 )

Table 1. Demographic distribution of participants

\begin{tabular}{|c|c|c|c|}
\hline Variable & Response & Frequency & Percentage \\
\hline \multirow[t]{2}{*}{ Sex } & Male & 41 & 58.6 \\
\hline & Female & 29 & 41.4 \\
\hline \multirow[t]{8}{*}{ Age } & $19-20$ & 2 & 3.0 \\
\hline & $21-30$ & 14 & 21.2 \\
\hline & $31-40$ & 11 & 16.7 \\
\hline & $41-50$ & 8 & 12.1 \\
\hline & $51-60$ & 8 & 12.1 \\
\hline & $61-70$ & 16 & 24.2 \\
\hline & $>70$ & 7 & 10.6 \\
\hline & & Mean age $=49$ & Standard deviation $=18$ \\
\hline \multirow[t]{2}{*}{ Specific Ward Admitted } & Orthopaedic & 35 & 50.0 \\
\hline & Neurosurgery & 35 & 50.0 \\
\hline \multirow[t]{5}{*}{ Marital Status } & Single & 21 & 31.3 \\
\hline & Married & 32 & 47.8 \\
\hline & Widowed & 12 & 17.9 \\
\hline & Separated & 1 & 1.5 \\
\hline & Divorced & 1 & 1.5 \\
\hline \multirow[t]{2}{*}{ Religion } & Christianity & 47 & 68.1 \\
\hline & Islam & 22 & 31.9 \\
\hline \multirow[t]{4}{*}{ Ethnicity } & Yoruba & 57 & 82.6 \\
\hline & Igbo & 5 & 7.2 \\
\hline & Hausa & 1 & 1.4 \\
\hline & Others & 6 & 8.7 \\
\hline
\end{tabular}




\begin{tabular}{|c|c|c|c|c|}
\hline \multirow{4}{*}{\multicolumn{2}{|c|}{$\begin{array}{l}\text { Highest } \\
\text { Education }\end{array}$}} & No Formal Education & 5 & 7.5 \\
\hline & & Primary & 12 & 17.9 \\
\hline & & Secondary & 31 & 46.3 \\
\hline & & Tertiary & 19 & 28.4 \\
\hline \multirow{4}{*}{\multicolumn{2}{|c|}{ Occupation }} & Civil- Servant & 17 & 24.3 \\
\hline & & Self Employed & 31 & 44.3 \\
\hline & & Retired & 13 & 18.6 \\
\hline & & Unemployed & 9 & 12.9 \\
\hline \multirow[t]{3}{*}{ Reason for admission } & & $\begin{array}{l}\text { Orthopaedic injuries \& } \\
\text { Surgeries }\end{array}$ & 25 & 35.7 \\
\hline & & Other bone diagnoses & 10 & 14.0 \\
\hline & & $\begin{array}{l}\text { Spinal Cord } / \text { Head } \\
\text { Injury }\end{array}$ & 35 & 50.0 \\
\hline
\end{tabular}

\subsection{Patients' Awareness of PI and Source of Information}

Data show that $54.3 \%$ understood the meaning of PI; of which $(69.4 \%)$ claimed they learned from healthcare providers. However, for $61.7 \%$, the nurses/doctors had not explained the causes or the risk factors to them; therefore $66.1 \%$ did not see themselves as being at risk despite their impaired mobility status (Table 2).

Table 2. Patients' /and or caregivers' awareness of PI and source of information about risk factors of PI

\begin{tabular}{lllll}
\hline Variable & Response & $\begin{array}{l}\text { Frequency } \\
\mathbf{( \% )}\end{array}$ & Mean & $\begin{array}{l}\text { Standard } \\
\text { deviation }\end{array}$ \\
\hline Patients knowledge of meaning of PI & Yes & $38(54.3)$ & 1.5224 & 0.58668 \\
& No & $32(47.8)$ & & \\
\hline Source of information & Health workers & $25(69.4)$ & 1.6667 & 1.21890 \\
& Friends & $4(11.1)$ & & \\
& Internet & $4(11.1)$ & & \\
& Others & $3(8.3)$ & & \\
& Yes & $23(37)$ & 1.6167 & \\
\hline $\begin{array}{l}\text { Whether or not the nurses or doctors have } \\
\text { explained the risk factors of PI during this }\end{array}$ & No & $37(61.7)$ & & \\
admission & & & & \\
\hline $\begin{array}{l}\text { Do patients consider themselves at risk for } \\
\text { PI? }\end{array}$ & Yes & $19(33.9)$ & 1.6607 & \\
\hline
\end{tabular}

\subsection{Patients' and/or Caregivers' Understanding Their Risk Factors for PI}

We examined the respondents' understanding of their risk factors. Specific areas of poor knowledge of risk factors were: incontinence (59.3\%), dragging self out of bed (56.5\%), loss of sensation (58.3), when the nurse drags than lifts $(66.7 \%)$ (Table 3).

Each correct response was scored 1, while incorrect response was scored 0; giving a total of 14.0. Scores were categorised into two levels. Scores $<7$ correct responses were interpreted as low reflecting low knowledge. In all $40(57.2 \%$ ) scored below 7 correct responses; $\bar{X}=1.42 \pm 0.49$ (table 3b). Mean knowledge of risk factors was $1.42 \pm 0.49$ and level of participation $(1.31 \pm 0.47)$. 
Table 3. Patients' and/or caregivers' understanding their risk factors for PI

\begin{tabular}{|c|c|c|}
\hline Response & Yes & No \\
\hline 1. Not eating adequately & $27(43.5)$ & $35(56.5)$ \\
\hline 2. Depression & $25(41.0)$ & $36(59.0)$ \\
\hline 3. Dragging self to sit out of bed & $26(42.6)$ & $35(57.4)$ \\
\hline 4. Inability to get out of bed & $32(52.5)$ & $29(47.5)$ \\
\hline 5. Spending most of the day in a wheelchair & $24(40.7)$ & $35(59.3)$ \\
\hline 6. Urine or fecal leakage (incontinence) & $25(41.7)$ & $35(58.3)$ \\
\hline 7. Inability to feel sensation or discomfort & $23(37.7)$ & $38(62.3)$ \\
\hline 8. When the body produces excess heat & $15(25.4)$ & $44(74.6)$ \\
\hline 9. Ageing process & $19(32.2)$ & $40(67.8)$ \\
\hline 10. low blood pressure & $20(33.3)$ & $40(66.7)$ \\
\hline 11. When the nurse drags rather than lift me in/out of bed & $21.0(34.4)$ & $40.0(65.6)$ \\
\hline 12. When lying on the bony prominences & $25.0(43.9)$ & $32.0(56.1)$ \\
\hline 13. Sitting in chair with prolonged pressure on bony prominences & $30.0(49.2)$ & $31.0(50.8)$ \\
\hline 14. Not lying on 4 inch foams or alternating mattress & $11.0(19.0)$ & $47.0(81.0)$ \\
\hline 15. Incorrect use of what should relieve pressure ulcer & $29.0(47.5)$ & $32.0(52.5)$ \\
\hline
\end{tabular}

Table 3b. Cumulative score for knowledge of risk factors

\begin{tabular}{lllll}
\hline Knowledge & Frequency & Percentage & Mean & SD \\
\hline Low & 40 & 57.1 & 1.42 & 0.49 \\
High & 30 & 42.9 & & \\
\hline
\end{tabular}

\subsection{Patients' and/or Caregivers' Level of Participation}

Findings showed that $65.2 \%$ engaged in activities to prevent PI while $34.8 \%$ did not participate in it. However, $49.3 \%$ of the respondents made efforts to change their position by self-help and $28.3 \%$ occasionally observed their skin for colour changes and take high protein $(63.2 \%)$ and adequate fluids $(63.6 \%)$. However, $32.7 \%$ never changed position every 2 hours by self-help or with relatives support, $38.9 \%$ of the respondents never put legs flat on the floor while sitting, $25.2 \%$ occasionally use moisturizers on the body, $45.3 \%$ never use incontinence pad (Table 4).

Table 4. Patient and/or caregivers' level of participation

\begin{tabular}{|c|c|c|c|c|c|c|}
\hline \multirow{3}{*}{$\begin{array}{l}\text { Variable/ Response } \\
\begin{array}{l}\text { Do you participate in pressure } \\
\text { ulcer prevention }\end{array}\end{array}$} & \multicolumn{3}{|l|}{ Response } & \multicolumn{3}{|c|}{ Frequency (\%) } \\
\hline & Yes & & & $30(65.2)$ & & \\
\hline & No & & & $16(34.8)$ & & \\
\hline Participation & Always & Occasionally & $\begin{array}{l}\text { Very } \\
\text { rarely }\end{array}$ & Never & Mean & $\begin{array}{l}\text { Standard } \\
\text { deviation }\end{array}$ \\
\hline Eating food high in calories & $30(55.6)$ & $5(9.3)$ & $4(7.4)$ & $15(27.8)$ & 2.07 & 1.3 \\
\hline $\begin{array}{l}\text { Eating food high in protein like } \\
\text { meat, fish, egg, etc. }\end{array}$ & $36(63.2)$ & $6(10.5)$ & $0(0)$ & $15(26.3)$ & 1.89 & 1.3 \\
\hline $\begin{array}{l}\text { Drinking adequate fluid i.e. } \\
\text { water, juices, etc. }\end{array}$ & $35(63.6)$ & $5(9.1)$ & $0(0)$ & $15(27.3)$ & 1.91 & 1.3 \\
\hline $\begin{array}{l}\text { Eating fruits and vegetables that } \\
\text { supply vitamins and minerals at } \\
\text { least } 3 \text { times }\end{array}$ & $32(57.1)$ & $8(14.3)$ & $0(0)$ & $16(28.6)$ & 2.00 & 1.3 \\
\hline
\end{tabular}




\begin{tabular}{lllllll}
\hline Changing position by self help & $25(46.3)$ & $9(16.7)$ & $3(5.6)$ & $17(31.5)$ & 2.22 & 1.3 \\
\hline $\begin{array}{l}\text { Changing position every 2 hours } \\
\text { by self-help or with relatives } \\
\text { support }\end{array}$ & $27(49.1)$ & $6(10.9)$ & $4(7.3)$ & $18(32.7)$ & 2.23 & 1.3 \\
\hline $\begin{array}{l}\text { Putting legs flat on the floor } \\
\text { while sitting }\end{array}$ & $11(19.4)$ & $12(22.2)$ & $10(18.5)$ & $21.38 .9)$ & 3.65 & 5.7 \\
\hline Using moisturisers on the body & $18(35.3)$ & $13(25.5)$ & $3(5.9)$ & $17(33.3)$ & 2.37 & 1.2 \\
\hline Using incontinence pad & $14(26.4)$ & $10(18.9)$ & $5(9.4)$ & $24(38.9)$ & 2.74 & 1.2 \\
\hline Using skin lubricants & $20(37.0)$ & $12(22.2)$ & $2(3.7)$ & $20(37.0)$ & 2.4074 & 1.3 \\
\hline $\begin{array}{l}\text { Observing the skin for colour } \\
\text { changes }\end{array}$ & $14(26.4)$ & $15(28.3)$ & $4(7.5)$ & $20(37.7)$ & 2.57 & 1.2 \\
\hline $\begin{array}{l}\text { Avoiding too hot or too cold } \\
\text { temperatures }\end{array}$ & $14(26.4)$ & $7(13.2)$ & $10(18.9)$ & 22 & 2.76 & 0.25 \\
\hline $\begin{array}{l}\text { Avoiding soiling my bed linens } \\
\text { and even if soiled, I call for } \\
\text { attention as soon as possible }\end{array}$ & $15(27.8)$ & $13(24.1)$ & $7(13.0)$ & 19 & 2.56 & 1.2 \\
\hline \begin{tabular}{l} 
Doing passive exercises \\
\hline
\end{tabular} & $15(28.3)$ & $15(28.3)$ & $5(9.4)$ & 18 & 2.49 & 1.2 \\
\hline
\end{tabular}

In categorizing the level of participation, the range of scores were $0-56$. Scores $\leq 28$ was interpreted as low level of participation, while scores $\geq 28$ was considered high level participation. Results showed that 16 (30.8\%) were not consciously engaging in PI prevention among the study cohort (table $4 \mathrm{~b}$ )

Table 4b. Cumulative score for level of participation

\begin{tabular}{lllll}
\hline $\begin{array}{l}\text { Level of } \\
\text { Participation }\end{array}$ & Frequency & $\%$ & $\bar{x}$ & $\mathrm{SD}( \pm)$ \\
\hline High & 36 & 69.2 & 1.31 & 0.47 \\
Low & 16 & 30.8 & & \\
\hline
\end{tabular}

\subsection{Respondents' Perspective About Participation in PI Prevention}

We examined respondents' perspective about participating in PI prevention. Findings indicated that $93.8 \%$ really wanted to participate, 50.8\% were not clear know about their role in PI prevention and $95.3 \%$ believed their family/caregivers can contribute to prevent PI (Table 5).

Table 5. Respondents perspective about participation in PI prevention

\begin{tabular}{lll}
\hline Variable & Response & $\begin{array}{l}\text { Frequency } \\
\mathbf{( \% )}\end{array}$ \\
\hline $\begin{array}{l}\text { Do patients really want to participate } \\
\text { pressure ulcer }\end{array}$ & Yes & $\begin{array}{l}61(93.8) \\
4(6.2)\end{array}$ \\
\hline Do you know your role in PIP & No & $32(49.2)$ \\
& Yes & $33(50.8)$ \\
\hline $\begin{array}{l}\text { Do think your family caregiver can } \\
\text { contribute to PI Prevention }\end{array}$ & No & $61(95.3)$ \\
\hline $\begin{array}{l}\text { Do you think your participation in care } \\
\text { would be beneficial }\end{array}$ & No & $3(4.7)$ \\
\hline & Nos & $59(92.2)$ \\
& Indifferent & $2(3.2)$ \\
& & $3(4.7)$ \\
\hline
\end{tabular}




\subsection{Patients' and/or Caregivers' Perceived Barriers to Participation in PI Prevention}

Findings suggested that inadequate information posed a barrier to effective participation in PI prevention $(65.5 \%)$. This is followed by the belief that only nurses know what to do to prevent its occurrence $(60.3 \%)$. Respondents $(56.7 \%)$ also noted that their caregivers were not allowed to stay long enough on the wards to participate in PI prevention (Table 6).

Table 6. Perceived barriers to participation in PIP

\begin{tabular}{llllll}
\hline Barriers & A & $\mathbf{U}$ & $\mathbf{D}$ & $\bar{X}$ & SD \\
& Freq. (\%) & Freq. (\%) & Freq. (\%) & & \\
\hline Does not understand the specific roles & $21(34.4)$ & $6(9.8)$ & $34(55.8)$ & 3.3 & 1.38 \\
\hline Inadequate information/instruction from nurses & $41(65.5)$ & $12(19.2)$ & $10(15.8)$ & 2.41 & 1.16 \\
\hline Only nurses know what to do & $35(60.3)$ & $13(31.7)$ & $10(15.8)$ & 3.45 & 1.1 \\
\hline Pain experienced during repositioning & $37(62.7)$ & $12(20.3)$ & $10(17.0)$ & 3.58 & 1.16 \\
\hline Not feeling need to change position & $34(56.7)$ & $13(21.7)$ & $13(31.7)$ & 3.47 & 1.12 \\
\hline A feeling of incompetence and inadequacy & $33(56.0)$ & $12(20.3)$ & $14(23.8)$ & 3.10 & 1.27 \\
\hline $\begin{array}{l}\text { Caregivers are not allowed to stay for long on } \\
\text { the ward }\end{array}$ & $34(56.7)$ & $12(20.0)$ & $13(21.7$ & 3.47 & 1.12 \\
\hline
\end{tabular}

Key: A-agreed; U=Undecided; $\mathrm{D}=$ Disagree.

\subsection{Hypotheses}

Two (2) hypotheses were generated and tested. $\mathrm{H}_{\mathrm{o}} 1$ showed a significant association between level of education of patient and/or caregiver and participation in the prevention of pressure ulcer $\left(X^{2} \mathrm{cal}=14.79, \mathrm{p}<0.05\right)$ (Table 7).

Table 7. Association of level of education and participation in PIP

\begin{tabular}{|c|c|c|c|c|c|}
\hline \multirow[t]{2}{*}{ Highest Level of education } & \multicolumn{2}{|c|}{ Patient participation } & \multirow[t]{2}{*}{ Total } & \multirow[t]{2}{*}{$\mathrm{X}^{2}$} & \multirow[b]{2}{*}{ P value } \\
\hline & High & Low & & & \\
\hline NO FORMAL EDUCATION & 1 & 1 & 2 & \multirow{5}{*}{14.79} & \multirow{5}{*}{0.002} \\
\hline PRIMARY & 2 & 8 & 10 & & \\
\hline SECONDARY & 16 & 4 & 20 & & \\
\hline TERTIARY & 16 & 3 & 19 & & \\
\hline TOTAL & 35 & 16 & 51 & & \\
\hline
\end{tabular}

$\mathrm{H}_{\mathrm{O}} 2$ showed a no significant difference between specific units of admission and level of participation in PI prevention $(\mathrm{F}=2.36 ; \mathrm{p}=0.13>0.05)\{$ Table 8$)$

Table 8. Difference between the specific wards of admission and their level of participation

\begin{tabular}{lllllll}
\hline $\begin{array}{l}\text { Groups (Orthopaedics } \\
\text { and Neurosurgery) }\end{array}$ & $\begin{array}{l}\text { Sum of } \\
\text { squares }\end{array}$ & Df & Mean square & F-statistic value & P value \\
\hline Between Groups & 0.583 & 1 & 0.583 & & \\
Within Groups & 12.123 & 49 & 0.247 & 2.36 & 0.13 \\
Total & 12.706 & 50 & & & \\
\hline
\end{tabular}




\section{Discussion}

Impaired physical mobility is a major risk factor for PI, thus the need for effective preventive interventions. Clinical guidelines emphasize the importance of patients' participation in simple interventions such as repositioning, skin care and nutrition. However, this participation cannot be assumed but must be active and collaborative with the nurses (N Schoeps et al, 2016). Studies reported patients' willingness to assume an active role in their own care howbeit to some extent; and they value this participation (Kolovos, Kaitelidou, Lemonidou, Sachlas \& Sourtzi, 2016; Tobiano et al., 2016). There is therefore a need for changes in the organization of nursing care, communication skills and educational strategies to optimise patients' participation. This avowal is consistent with our findings as $93.8 \%$ of the study cohort indicated willingness to participate but lacked information on what their roles would be. Similarly, most respondents $(65.5 \%)$ judge lack of information as a barrier to participation. It should be noted that; although the study cohort understood the meaning of PI, they confirmed that the care providers did not explain the risk factors to them. It is understood that PI is a patient safety issue in hospitals, thus if patients are sufficiently motivated and empowered through knowledge-sharing, they could monitor their own safety (Tobiano et al., 2016). This, according to the authors raise a need for nursing training on patient-centred approaches to care. From our study $66.1 \%$ claimed they were not at risk for PI, despite their impaired mobility status which literature confirms is the most predictor of PI occurrence (Mclnnes et al., 2014). It may be deduced that participation in care may not come easy if patients are not informed of their risk factors.

In regards to level of participation, patients and their caregivers seem to engage in some self-help interventions despite the fact that they were not given definite instructions by nurses. For example, $63.2 \%$ always eat foods high in protein to boost their nutritional status and $49.1 \%$ engage is 2 hourly repositioning by self-help. However, $10.9 \%$ occasionally reposition themselves by self-help every 2 hours. Gillespie et al. (2014), in a systematic review noted that repositioning is an integral part of PI prevention with sound theoretical and scientific rationale. It is therefore widely recommended in practice, despite the uncertainty in research reports on the most effective frequency and tilt $\left(30^{\circ}\right.$ or $\left.90^{\circ}\right)$. Yet, repositioning remains a largely supported intervention in PI prevention.

Our findings support previous findings; that pain and discomfort may deter patients from responding to the natural stimulus of repositioning (Mclnnes et al., 2014). This was also supported by Briggs et al., 2013. In our study, $56.0 \%$ reported a feeling of incompetency and inadequacy in PI prevention. This may be related to lack of structured guidance by nurses. There was a significant association between level of education and participation $(p<0.05)$; suggesting that the level of education can significantly predict patents' participation in care. It follows that when education is tailored to patient's level of understanding, the outcome can be optimised. On the other hand, there was no difference between specific ward of admission and the level of participation in PI prevention.

\section{Conclusion}

The findings from this study correctly confirm patients' willingness to be actively involved in their own care; within the limit of their ability and the extent of information available to them. It is however important that nurses/ doctors educate the patients on the risk factors for PI, in order to strengthen and motivate their active engagement thereby reducing PI development. We recommend that the principle of patients' participation in care should be integrated into the hospital policy, as a standard of practice. Furthermore the PI prevention should be tailored to patients' level of understanding to facilitate active participation.

\section{Acknowledgement}

We acknowledge the patients who participated in the study. We also express our gratitude to the nurses on the respective wards for their support during data collection.

\section{References}

Aujoulat, I., d'Hoore, W., \& Deccache, A. (2007, April). Patient empowerment in theory and practice: polysemy or cacophony?. Patient Education and Counseling, 66(1), 13-20.

Black, J., Edsberg, L., Baharestani, M., Langemo, D., Goldberg, M., McNichol, L., ... the National Pressure Ulcer Advisory Panel. (2011). Pressure ulcers: avoidable or unavoidable? Results of the National Pressure Ulcer Advisory Panel consensus conference. Ostomy Wound Management, 57(2), 24-37.

Briggs, M., Collinson, M., Wilson, L., Rivers, C., McGinnis, E., Dealey, C., .. Nixon., J. (2013). The prevalence of pain at pressure areas and pressure ulcers in hospitalised patients. BMC Nursing, 12(1), 19. 
Cilibertia, M., De Laraa, F., Serraa, G., Tafuroa, F., Iazzettaa, F. M., De Martinoa, V., ...Veneri, M. R. (2014, June). Effective management of pressure ulcers using Hydrofibre technology with silver ions. Wound Medicine, 5, 40-44.

Davis, R., Sevdalis, N., Pinto, A., Darzi, A., HonFREng, \& Vincent, C. (2011). Patients attitudes towards patient involvement in safety interventions: Results of two exploratory studies. Health Expectations, 16(4), e164-e176.

Gillespie, B. M., Chaboyer, W. P., McInnes, E., Kent, B., Whitty, J. A., \& Thalib, L. (2014). Repositioning for pressure ulcer prevention in adults. Cochrane Database of Systematic Reviews, (4).

Kolovos, P., Kaitelidou, D., Lemonidou, C. Sachlas, A., \& Sourtzi, P. (2016). Patients' perceptions and preferences of participation in nursing care. Journal of Nursing Research, 21(4), 290-303.

Kuijpers, W., Groen, W., Aaronson, N., \& Harten, W. (2013). A Systematic Review of Web-Based Interventions for Patient Empowerment and Physical Activity in Chronic Diseases: Relevance for Cancer Survivors. Journal of Medical Internet Research, 15(2), e37.

Latimer, S., Chaboyer, W., \& Gillespie, B. (2014). Patient participation in pressure injury prevention: Giving patient a voice. Scand. Journal of Caring Science, 28(4), 648-56.

Mclnnes, E., Chaboyer, W., Murray, E., Allen, T., \& Jones, P. (2014). The role of patients in pressure injury prevention: a survey of acute care patients. BMC Nursing, 13(41).

Moore, Z., Cowman, S., \& Conroy, R. (2011). A randomised controlled clinical trial of repositioning, using the 30-degree tilt, for the prevention of pressure ulcers. Journal of Clinical Nursing, 20, 2633-2644.

Näsström, L., Jaasma, T., Idvall, E., Årestedt, K., \& Strömberg, A. (2014). Patient participation in patients with heart failure receiving structured home care - A prospective longitudinal study. BMC Health Services Research, 14, 633 .

National Pressure Ulcer Advisory Panel, European Pressure Ulcer Advisory Panel, \& Pan Pacific Pressure Injury Alliance. (2014). Prevention and Treatment of Pressure Ulcers: Quick Reference Guide 2014. Cambridge Media: Osborne Park, Western Australia.

Rafii, F., Soleimani, M., \& Seyed-Fatemi, N. (2010). Concept Analysis of Participation of Patient with Chronic Disease: Use of Hybrid Model. Iranian Journal of Nursing and Midwifery Research, 23(67), 35-48.

Schofield, R., Porter-Armstrong, A., \& Stinson, M., (2014). Reviewing the Literature on the Effectiveness of Pressure Relieving Movements. Nursing Research and Practice, Sep 17.

Shaghayegh, V., Leila, H., Somayeh, H., \& Zeinan, H. (2014). Patient involvement in healthcare Decision making: A review. Iranian Red Crescent Medical Journal, 16(1), e12454.

Souliotis, K. (2016). Patients' participation in contemporary health care: Promoting a versatile patient role. Health Expectations: Oxford, 19(2), 175-178.

Schoeps, L. N., Tallberg, A.-B., \& Gunningberg, L. (2016). Patients' knowledge of and participation in preventing pressure ulcers- an intervention study: Patients' knowledge of preventing pressure ulcers. International Wound Journal, 14(2), 344-348.

Tobiano, G., Bucknall, T., Marshall, A., Guinane, J., \& Chaboyer, W. (2016). Patients' perception of participating in nursing care on Medical Wards. Scandinavian Journal of Caring Sciences, 30(2), 260-70.

\section{Copyrights}

Copyright for this article is retained by the author(s), with first publication rights granted to the journal.

This is an open-access article distributed under the terms and conditions of the Creative Commons Attribution license (http://creativecommons.org/licenses/by/4.0/). 